\title{
Determining Factors for Implementing Green Supply Chain Management in the Construction Industry: A Literature Review
}

\author{
Mochammad Agung Wibowo, ${ }^{1}$, Naniek Utami Handayani ${ }^{2}$, Anita Mustikasari ${ }^{2}$, Asri \\ Nurdiana $^{1}$, and M. Nur Soleh ${ }^{1}$ \\ ${ }^{1}$ Department of Civil Engineering, Faculty of Engineering, Diponegoro University, Semarang, \\ Indonesia 50275 \\ ${ }^{2}$ Department of Industrial Engineering, Faculty of Engineering, Diponegoro University, \\ Semarang, Indonesia 50275
}

\begin{abstract}
The construction industry plays a significant role in improving the quality of the built environment, but its activities also impact the wider environment. Supply chain management (SCM) aims to increase the efficiency of the construction process through improvements in the quality, cost, and time frame of projects. Green SCM has as its purpose reducing environmental impact by opting for eco-friendly materials starting from the design phase in the choice and procurement of materials to be used in construction projects. This study aims to adopt GSCM concepts of the manufacturing industry for application in the construction industry. A literature review was conducted to learn from previous research about the implementation of GSCM in manufacturing to serve as a basis for adopting of this concept for the purposes of building criteria for the implementation of GSCM in the construction industry.
\end{abstract}

\section{Introduction}

The contributions of the construction industry to infrastructure development in Indonesia have encouraged equitable economic growth. However, the construction industry has the reputation of contributing bad impact on the environment [1]. Effective management systems are essential to ensuring that projects are completed on time and within budget while helping project managers monitor progress [2,3]. At the same time, stakeholders need efficiency in the activity flow of construction projects compatible with a lean focus and the reduction of energy consumption and waste [4].

The supply chain in the construction industry is different from the manufacturing industry [5]. However, the unavoidable problem of fragmentation should be solved so that inefficiency in construction can be reduced or eliminated. Supply chain management is implemented to enhance efficiency and accuracy as reflected in quality, cost, and delivery time. GSCM prioritizes the minimization of waste and energy use and the procurement of environmentally friendly materials. The implementation of GSCM in construction projects

Corresponding author: naniekh@,ft.undip.ac.id 
is meant to bring the concept of eco-friendliness into every process, from upstream to downstream and through all of the PLC phases. The modeling of eco-friendly concepts at all phases in the project life cycle with the aim of creating green supply chains (GSCs) in construction projects requires further study. Therefore, this study will conduct research on the implementation of GSCs in construction, based on project life cycle. The concept of GSCs in manufacturing can be adopted in construction projects. The implementation of GSCs in a construction project should apply indicators to each PLC phase which need to be assessed from the beginning until the end of the construction process. The purpose of this research is to adopt GSCM concepts of the manufacturing industry for application in the construction industry.

\section{Green Supply Chain Management}

\subsection{The Concept of Green Supply Chain Management}

Green supply chain management (GSCM) is defined as the integration of sustainable practices into upstream and downstream supply chain management6. GSCM consists of green product design, green materials management, green manufacturing processes, green distribution and marketing, and reverse logistics (RL) [6].

Green Product Design opens up opportunities to diminish any environmental impacts inherent in the establishment of new products and production processes. Green product design consists of two primary conceptions: environmentally conscious design (ECD) and life-cycle assessment (LCA). LCA is defined by its focus on analysing the environmental burdens of processes and products over their entire life cycle [7][8]. ECD refers to concepts and practices related to designing products while keeping environmental considerations in mind.

Green materials management is a way to substitute less hazardous activities or materials that replace more harmful ones. It is classified into two processes: green materials selection and green materials sourcing. The criteria for materials that can be processed in green materials management include that materials used in a product must be easy to separate, be adaptable, or can be used to streamline existing processes [8-9].

Green manufacturing processes consist of three main phases: resource utilization decrement, waste decrement, and emission decrement. Green manufacturing process aims to minimise the total amount of waste at the manufacturing phase indirectly by decreasing energy and resource utilization [10]. Emission decrement has two essential characteristics: control and prevention. Control means emissions and waste are trapped, stored, treated, and disposed of using pollution control equipment. Prevention means decreasing, changing, or preventing emissions and waste together through better materials substitution, recycling, reuse, or process innovation [6].

Green Distribution and Marketing refers to the promotion or advertising of products, changes in production processes, or packaging changes that are weighed in terms of environmental criteria [11].

Reverse logistics, another significant component of GSCM, has the objective of collecting, distributing, and managing products until they are delivered to customers. Reverse logistics encompass the recycling, reusing, and remanufacturing of materials. Benefits of recycling include extraction of basic materials, diminished energy usage, and reduced air and water pollution [6]. Examples of reuse include the utilization of reusable packaging or shipping materials [12]. 


\section{Green SCM Frameworks in the Construction Industry}

Based on research of GSCM in manufacturing, this paper proposes to elaborate the implementation of GSCM in construction projects by adopting the concept of GSCM used in manufacturing to the construction industry but with various adjustments and modifications. This application of GSCM to construction is expected to reduce waste, energy usage, and negative impacts of construction projects on the environment.

\subsubsection{The GSCM Concept Applied to the Construction Industry}

GSCM is defined as the integration of sustainable practices into upstream and downstream supply chain management to bring long-term benefits through the application of responsible environmental and social behavior in all supply chain members [6-13].

The framework of green supply chain process implementation in the construction industry will now be explained in greater detail.

The Green design has as a benefit to diminish environmental impact resulted from the establishment of construction design and processes. Green design consists of two main elements: LCA to strengthen construction development so the overall negative environmental impact of construction is reduced, and the concept of ECD to design construction activities while keeping environmental considerations firmly in mind.

The Green materials management refers to ways of substituting more benign activities or materials for potentially hazardous ones. The criteria used in selecting materials that can be processed in green materials management include that materials used in construction should be easy to separate, adaptable, or useful in streamlining existing processes.

The Green construction aims to maximise the conservation of resources and reducing construction activities that incur negative impacts for the environmental while achieving the goal of savings in the four resource areas (energy, land, water, and materials) in addition to ensuring environmental protection.

The Green Marketing Management consists of green customer education, green customer social responsibility, and green image promotion. The aim of green marketing management is to promote or advertise project construction using environmental criteria.

The Reverse logistics are defined as a set of activities to manage materials that potentially increase waste streams via strategies consisting of reuse, recycling, and remanufacture. Recycling is described as a procedure to reuse materials that may otherwise be considered waste in a form other than the primary use. Reuse means a material is used again for the same purpose or may find a new product life in a distinct function.

\subsubsection{The Dimensions of the GSCM Concept in the Construction Industry}

The proposed elements of each dimension of GSCM concepts in the construction industry have been broken down into several components. There are thirteen dimensions in Green Design concept which are Eco-Design [14-16], Innovation Capability [17], Environment Collaboration with Customer [18-22], Product Safety [23], Occupational Health and Safety [23], Pollution Prevention [23], Resource Conservation and Waste Management [23], Appropriate Site Development [24], Energy Efficiency and Conservation [23-25], Water Conservation [24-25], Material Resource and Cycle [24], Indoor Health and Comfort [24], and Building and Environment Management [24].

In Green Materials Management concept, there are three dimensions: Procurement / Purchasing [26-28], Government Regulation and Legislation [29, 30-31], and Environment Certification [18-19, 22, 32-33]. While in Green Construction Processes, the dimensions 
are Production Cost [14, 34], Waste Management [35-13, 10], Pollution Control / Environment Treatment [15, 36-37], Quality Control [38], Employment Practices [37, 39], Resource Management [40-41], and Health and Safety [15].

In Green Marketing Management concept, Green Management / Marketing Policy [17], Green Corporate Social Responsibility [42-43], Green Customer Education [25], and Green Image Promotion [25] are recognized as its dimensions. Whereas, the concept of Reverse Logistics has three concepts: Recycling [6, 12, 18, 32], Reuse [6, 12, 18, 32, 42], and Remanufacture [14, 21, 26, 39, 48].

\section{Research Methodology}

A literature review is conducted to manage the diverse knowledge pertaining to a specific research topic [44]. The researchers conducted a literature-review-based study to address the research objectives [45], whereby a literature review is a decisive tool that supports the researcher in the following ways: by mapping, consolidating, and evaluating the existing academic structure of the identified field by developing the scope of further opportunities through identifying key research gaps in the existing body of research.

\section{Discussion}

The GSCM concepts are applied to manufacturing industries for the purpose of environmental sustainability. This concept is being applied to the construction industry to reduce the impact of construction on the environment. In the early stages of research, the researchers conducted a literature review of the GSCM concept in the manufacturing industry and tried to adapt the findings for use in the construction industry. The dimensions of GSCM in the construction industry are divided into five concepts: Green Design, Green Materials Management, Green Construction Processes, Green Marketing Management, and Reverse Logistics. Each of these concepts represents a measurement dimension of green supply chains.

These elements will be reviewed based on PLC in the construction industry. At the initiation phase, the owner should consider green initiation to a project. Green initiation includes green building, green construction, and all concepts that minimize waste and energy. At the design phase, planners have to think about green product design and green materials management. The construction phase is the most complex stage of the project life cycle, and it is also one of the phases that determines the success of GSCM implementation. At the construction phase, all stakeholders involved have a responsibility for the implementation of GSCM concepts. The GSCM indicators at this phase are green materials management and green construction. At the operation and maintenance phase, the owner should take green operation and maintenance concepts into consideration.

Each GSCM concept is composed of multiple dimensions. The dimensions of the green initiation concept are eco-design and environmentally conscious design. The dimensions of green product design are design, innovation capability, product safety, environmental control, and building and environmental management. The dimensions of green materials management are materials planning, procurement/purchasing, materials storage, materials handling, green materials selection, green materials sourcing, and government regulations and legislation. The dimensions of green construction are green transportation, on-site management and planning, site operation, residual, environment society, and reverse logistics. The dimensions of green operation and maintenance are green building and green management policy. 
GSCM in the manufacturing industry can be adopted in the construction industry, it includes the concepts of green product design, green materials management, green manufacturing processes, green distribution and marketing, and reverse logistics [6]. From the literature study, the GSCM concepts in the construction industry are green initiation, green product design, green materials management, green construction, and green operation and maintenance. The GSCM concepts are similar in the manufacturing and construction industries in that environmentally friendly concepts should be applied from the beginning to the end phases and/or from upstream to downstream.

Based on the studies conducted, it is known that in order to reduce waste, energy consumption, and negative impact on the environment in the construction industry, GSCM concepts should be integrated from the initiation phase to the operation and maintenance phase.

\section{Conclusion}

Based on literature review, this paper has proposed a framework for the implementation of GSCM in construction industries. The framework includes the concepts and the dimensions of the GSCM model that was adapted from manufacturing industry. This study is rooted in a background of managed SCM in construction that has increased efficiency and productivity in construction projects. These benefits can be obtained in the construction industry by reducing waste, energy used, and negative impacts on the environment. The concepts of GSCM in construction include green initiation, green design, green materials management, green construction processes, and green operation and maintenance. These concepts can be integrated throughout the PLC from the initiation phase to the operation and maintenance phase.

\section{References}

1. J.S. Guzmán, M. Marrero, M.V.M. Delgado, A.R. De Arellano, Waste Manage 29, 9 (2009)

2. R.H. Mohring, F. Stork, Math Meth Oper Res 52, 501 - 515 (2000)

3. P. Schonsleben, M.K. Vodicka, K. Bunse, F.O. Ernst, CIRP Annals - Manuf Tech 59, 477-480 (2010)

4. P. Ball. J, Manuf. Tech. Manage. 26, 3 (2015)

5. Y. Rezgui, J. Miles, J. Constr. Eng. Manag 136, 5 (2010)

6. M. Ghobakhloo, S.H. Tang, N. Zulkifli, M. Ariffin, M, Int. J. Innov Manage. Tech. 4, 1 (2013)

7. M. Buyle, J. Braet, A. Audenaert, Renew. Sust. Energ. Rev. 26, 379-388 (2013)

8. A. Gungor, S.M. Gupta, Comput. Ind. Eng. 36, 4 (1999)

9. A.A. Hervani, M.M. Helms, J. Sarkis, Benchmarking: Int. J. 12, 4 (2005)

10. S.K. Srivastava, Int. J. Manag. Rev. 9, 1 (2007)

11. M.J. Cox, Earth Env 3 (2008)

12. J. Sarkis, J. Clean Prod. 11, 4 (2003)

13. P. Dadhich, A. Genovese, N. Kumar, A. Acquaye, Int. J. Prod. Econ. 164 (2015)

14. Q. Shi, J. Zuo, R. Huang, J. Huang, S. Pullen, Habitat Int. 40, 1-8 (2013)

15. K. Govindan, S. Rajendran, J. Sarkis, P. Murugesan, J. Clean Prod. 98, 66-83 (2015)

16. H.C. Zhang, T.C. Kuo, H. Lu, S.H. Huang, J. Manuf. Syst. 16, 5 (1997)

17. C.-C. Chen, H.-S. Shih, H.-J. Shyur, K.-S. Wu, Comput. Math. Appl. 64, 8 (2012)

18. D. Holt, A. Ghobadian, J. Manuf. Tech. Manag. 20, 7 (2009) 
19. A.H. Hu, C.-W. Hsu, IEEE Int. C. (2006)

20. R.D. Klassen, S. Vachon, Prod. Oper. Manag. 12, 3 (2003)

21. A. Paulraj, Bus. Strateg. Environ. 18, 7 (2009)

22. S. Vachon, Int. J. Prod. Res. 45, 18-19 (2007)

23. Y.-F. Wang, S.-P. Chen, Y.-C. Lee, C.-T. S. Tsai, Int. J. Hosp. Manag. 34, 263-273 (2013)

24. GBCI, GREENSHIP (2010)

25. G. Noci, Eur. J. Purch. Supply Manag. 3, 2 (1997)

26. P. Evangelista, M. Huge-Brodin, K. Isaksson, E. Sweeney, Implications for small business (2012)

27. S.U. Hoejmose, J. Grosvold, A. Millington, J. Purch. Supply Manag. 20, 4 (2014)

28. W. Yang, Y. Zhang, Y, J. Bus. Manage. Econ. 3, 5 (2012)

29. B.M. Beamon, Logist. Inf. Manage. 12, 4 (1999)

30. A. Hafezalkotob, Transport. Res. Part E Logist. Transport. Rev. 97, 228-250 (2017)

31. H. Min, W.P. Galle, Int. J. Oper. Prod. Man. 21, 9 (2001)

32. P. Rao, D. Holt, Int. J. Oper. Prod. Man. 25, 9 (2005)

33. Q. Zhu, J. Sarkis, J. Clean Prod. 14, 5 (2006)

34. T.E. Glavinich, P. DE, BOOK TOOLS (2008)

35. Q. Zhu, J. Sarkis, K. Lai, Transport. Res. Part E 44, 1-18 (2008)

36. A. Awasthi, S.S. Chauhan, S.K. Goyal, Int. J. Prod. Econ. 126, 2 (2010)

37. C. Bai, J. Sarkis, Int. J. Prod. Econ. 124, 1 (2010)

38. C.-W. Hsu, A.H. Hu, J. Clean Prod. 17, 2 (2009)

39. K. Muduli, K. Govindan, A. Barve, D. Kannan, Y. Geng, Resour. Conserv Recy. 76, 50-60 (2013)

40. C.-W.R. Lin, H-Y.S. Chen, Comput. Ind. 55, 2 (2004)

41. C. Wu, D. Bames, J. Clean. Prod. 112, 2114-2132 (2016)

42. S.-H. Chun, H.J. Hwang, Y.-H. Byun, Procedia-Soc. Behv. Sci. 186 (2015)

43. J. Moon, Sustain. Dev. 15, 5 (2007)

44. D. Tranfield, D. Denyer, P. Smart, British J. of Manag, 14(3), 207-222. (2003).

45. A. Fink, Thousand Oaks, Sage (1998). 